\title{
Sosok Dewa Indra Menurut Beberapa Karya Sastra Jawa Kuna
}

\section{Sugeng Riyanto}

Keywords: iconography, philology, Dewa Indra, Old Java, Prambanan

\section{How to Cite:}

Riyanto, S. Sosok Dewa Indra Menurut Beberapa Karya Sastra Jawa Kuna. Berkala Arkeologi, 14(2), 73-77. https:// doi.org/10.30883/jba.v14i2.704

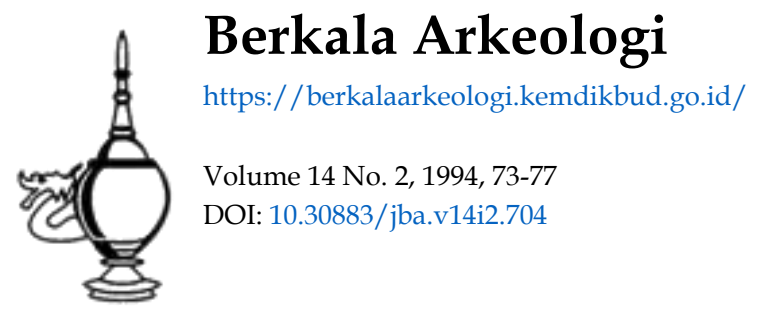

\section{(c) () (2)}

This work is licensed under a Creative Commons Attribution-NonCommercial-ShareAlike 4.0 International License. 


\title{
SOSOK DEWA INDRA MENURUT BEBERAPA KARYA SASTRA JAWA KUNA
}

\author{
Sugeng Riyanto \\ (Pusat Penelitian Arkeologi Nasional)
}

\section{Pendahuluan}

Karya sastra Jawa Kuna merupakan salah satu data tekstual yang dianggap penting. Selain mengandung keterangan sejarah, didalamnya juga terdapat keterangan tokoh raja, pemerintahan, perikehidupan dalam lingkungan istana, kehidupan rakyat, dan sebagainya (Boechari, 1977:6). Suatu hal yang tidak kalah pentingnya adalah adanya keterangan tentang ikonografi baik dewa maupun dewi, terutama dalam lingkungan agama Hindu (Sedyawati, 1978:69). Hal ini berarti bahwa dengan perlakuan tertentu terhadap karya sastra, aspek-aspek kehidupan masyarakat Jawa Kuna dapat diketahuı dan dipahamı.

Sehubungan dengan hal tersebut, tulisan singkat ini dimaksudkan untuk menggambarkan sosok Dewa Indra yang didasarkan pada kajian terhadap beberapa karya sastra Jawa Kuna. Selama ini Dewa Indra dikenal sebagai salah satu darı dewa-dewa lokapāla' seperti yang dipahatkan pada Candi Çiva, Prambanan. Dengan kajian yang lebih luas diharapkan dapat terungkap gambaran dari sisi lain Dewa Indra yang pada gilirannya juga dapat diketahui kecenderungan para pujangga dalam menampilkan figur Dewa indra.

\section{Dewa Indra Dalam Karya Sastra Jawa Kuna}

Dalam hal ini pembicaraan tidak ditujukan pada telaah kebahasaan, akan tetapi lebih pada gambaran deskriptıf dari bait-bait yang menyebut Dewa Indra. Sebagai sumber dipilih karya sastra balk dalam bentuk kakawin, prosa, maupun kıdung seperti terlihat di bawah ini

\section{Kakawin Ramayana ${ }^{2}$}

Dalam kakawin ini Dewa indra terutama disebut pada pupuh XXIV yaitu ketika Indra memberı Rama panah guhya-wijaya dan kereta beserta saisnya yang bernama Matali untuk mengalahkan Rawana

"13.a. yatnâwèh ta sirâstra guhyawijaya brahmâstra lâwan ratha.

b. tan ièn sârathi matalik..." (Zoetmulder).

Dewa-dewa lokapala adalah para dewa yang bertugas menjaga mata angin. Secara lengkap dewa-dewa tersebut adalah: indra. Agni, Yama, Nainta. Waruna, Ways. Kıwera, dan Isana

Nama penulis kakawn ini tidak diketahui, sedangkan wakhd penulisanmya diperkiakan sebelum masa Sindok (Zoetmuder, 1983: 294)
Pada bait 53 pupuh yang sama, yaitu ketika Rama memberi ajaran astabrata, disebutkan bahwa sifat Dewa Indra adalah menurunkan hujan

"53. a. Nihan brata ni sang hyang indrälapěn

b. sirâng hudanakèn tumrepting sagat. "(ibıô)

\section{Udyogaparwa ${ }^{3}$}

Karya sastra bentuk prosa ini Indra digam. barkan dalam adegan perang. Pertama melawan raksasa Trisirah: "lumampah ta sira luměpasing daitya bajsa tikșrna" (Zoetmulder, 1958), (berjalanlah ia (Indra) datang dan melepaskan bajra yang tajam pada raksasa itu). Ke-dua ketıka melawan Wreta: "tumuluy umarêng kadewatan aprang ta ya lawan sang hyang indra" (ibid.), (segera Wreta) datang menuju kahyangan dan berperang melawan Dewa Indra)

Di samping itu terdapat bans yang menyebut Indra sebagai penghuni surga. "Pahyangan drestanterika (indra) amangguha lara lawan stri bhatäri Sacr' (Zoetmulder), (Demikian pula contoh (Indra) di surga, la tertımpa kesengsaraan bersama istrinya, Dewi Saci).

\section{Kakawin Arjunawiwaha ${ }^{4}$}

Dalam kakawin ıni Indra banyak disebut karena kisah inı terkait langsung dengan kedudukannya sebagai penguasa surga. Dicentakan

${ }^{3}$ Dalam hal ini Dewa Indra terutama disebut daiam cerita sisipan yang disebut Cerita Indrawijaya. Dalam naskah ketikan Udyogaparwa milik Prof. Or. P.J Zoetmulder. Cerita Indrawijaya terdapat pada halaman 5 sampai 17 dari 156 halaman teks Jawa Kuna Udyogaparwa. Udyogaparwa merupakan bagian ke5 dari urutan wracarita Mahabharata dan dakam perkembanganmya dı Jawa, ktab ını diadaptası dalam bentuk prosa bartahasa Jawa Kuna. Seperti parwaparwa yang lain, udyogapaswa tidak diketahul pengarangnya, sedangkan waktu penulisannya diperiorakan sekitar abad X-XI M (Zoetmudder, 1983: 80 dan 110)

- Teks Kakawin Ajunawnaha dan tejemahan dalam bahasa Belanda telah ditertitkan oleh R.Ng Poerbatjaraka dengan unou Agunawnwaha. Teks en Vertaling. Kakawn ini juga menjadi bahan disertas oleh Kuntara Wiryamartana. Ajunawmaha Transformasi Teks Jawa Kuna Lewat Tanggapan dan Penciptaan di Lingkungan Sastra Jawa (Yogyakarta: F.S. UGM, 1987). Kakamn ini ditulis pada masa pemenntahan pemerintahan Raja Erlangga (1019.1042 M) antara tahun 1028-1035 M oleh mpu Kanwe 
bahwa hanya Arjuna yang dapat menyelamatkan surga dan ancaman serangan Niwātakawaca. Bait yang penting dalam pupuh ini terdapat pada pupuh XXIII yang menyebutkan ketika Indra bersama bala tentara dewa keluar dari benteng dengan kendaraan gajah Erāwana dan senjata berupa bajra. Dalam kakawin disebutkan:

"1. a. sang hyang Surapati mětu sangka ri(ng) kuta lawan <su>rabala gumuruh,

b. Erāwana gajapati rĕngga-r unggu nira ratna kadi gunung apuy.

c. bajrāyuddha marék i (payung] sîâ (payung) garuda roma kadi jaladhara". (Wiryamartana, 1987: 201).

Kemudian pada pupuh XXVIII Indra digambarkan ketika mengobati apsara yang teriuka atau mati dengan amerta:

"3. a. IIng]kang surāpsara mati len hanâsakit,

b. sına(ng) grahêng amrit(w)a těkap [ing] Surādhipa". (ibid: 214)

\section{Kakawin Smaradahana ${ }^{5}$}

Pada pupuh XXIX disebutkan bahwa kediaman Dewa Indra adalah surga: 6.c. "rin kendran swarga saphala dunuñěn". (Poerbatjaraka, 1931:44). Sedangkan pupuh XXXII menggambarkan Dewa Indra mengendarai gajah dengan pakaian perang menyongsong pasukan musuh:

6 a: "hyang Suranātha mangkat ahawan gajapatı rinasuk", (ibid 10)

\section{Kakawin Bharatayuddha ${ }^{6}$}

Kakawin yang mengisahkan peperangan antara Panddawa dan Korawa ini menyebut Dewa Indra terutama pada pupuh IX. Ketika itu huJan menjadi kurang deras; hujan rintik-rintik itu merupakan tanda baik untuk berperang. Dewa indra di langit mengikuti pasukan Panddawa untuk memberi restu:

"2.c. małra ng warshārarab manggalani lakunirāpangrahun seddung ādrěs,

Teks Jawa Kuna dan teljt:mahan datam bahasa Belanda telah ditertokan oleh R.Ng. Poertatjaraka, Smaradahana, Oud Javansche Teks met Vertaling. (Bandung: A.C.Nix \& Co.. 1931). Kakawin Smaradahana ditulis deh ma Dharmaja pada masa Kadiri, kira-kira musai tahun 115-1130 M (Poertbatjaraka. 1957: 22).

Teks Jawa kuna dan tenemahan dalam bahasa Indonesia telah ditertitkan oleh Sutijpto Wirjosuparto, Kakawin Bharglta Yuobha. (Jakarta:Bhratara, 1968). Kahorwin yang ditulis oleh mpu Sedah dan diteruskan oleh mpu Panuhth ini memuat candra sengkala: sanga kuora cudoha cendrama atau 1079 S'aka (1157) yang juga menupakan perkiaan waktu penulisannya (Wirjosuparto. 1968:10) d. āpan sang hyang Surendrādulur in awangawang māstawaken yan jayeng prang" (Wirjosuparto, 1968: 205).

\section{Kakawin Sutasoma ${ }^{\top}$}

Dalam kakawin ini terdapat dua bans yang dianggap penting sehubungan dengan figur Dewa Indra. Yang pertama pada pupuh XXXVI di mana disebutkan Dewa Indra turun dari kahyangan untuk menghidupkan Pangeran Sutasoma yang mati diterkam harimau:

"3. a. ndah hyang Surend'räidhipa ring Surālaya,

d. nyātaku hetwanyāhurip nrpātmaja." (Santoso, 1975: 244).

Yang ke-dua pada pupuh CXLVII, ketika Indra dengan air amerta yang keluar dari tubuhnya menghidupkan yang mati.

"8. c. ndā sighrā huddan amrtādrès umili mětu saka ri bhatara Bāsawa,

d. yekāng de hurip ing pějah. ." (Ibid: 599)

\section{Kidung Sri Tañjung ${ }^{8}$}

Kidung yang ditulis dalam bahasa Jawa Pertengahan terutama menyebut Dewa Indra pada pupuh III:

"32.a. Sang hyang Indra munggah ing dampar rum, amekar prabane,

b. sawa ratna angilabı, para resı tan kantun widadara sek,

c. supenuh, anangkil jěn ing batara, umyang swaraning gamělan,

d. sangka gěnta asauran, widadarı mangun pahyas." (Prijono, 1938: 18)

Terjemahan:

a.) Dewa Indra naik tahta di kerajaannya yang gemilang, prabhanya yang mengembang.

b.) terdiri dari bermacam-macam ratna yang berkilauan menyilaukan mata para resı dan widyadara penuh,

c.) berdesak-desakan menghormat dewa itu mendengung bunyi gamelan,

d.) sangka dan genta bersahut-sahutan, dan para bidadari selalu sibuk menghias dirı (Aminoedin, 1986. 57)

Teks Jawa Kina beserta tejemahan datam bahasa Inggris ada pada Soewito Sartoso, Sutasoma, a Study in Javanese Wajrayana, (New Delli: IAIC. 1975). Penulisnya adalah mpu Tantusar pada sektar tahun 1365-1389 M (Zoetrudder, 1983: 429-430)

- Kudung yang ditulis dalam bahasa Jawa Tengahan in mempuryai baryak versi dan tersebar terutama di Banywrongi dan Bali. Cerita ini berhasil direkonsouksi oleh Prijono sebagai bahan disertasimya. Sn Tanjung, een Oud-Javaansche Vernaad (Leiden. Proefschrift Rijks Univer-siteit Leiden. 1938). Nama penulis tidak diketahui, sedangkan waktu perwisan. nya diperkirakan antara 1500-1600 M (Prijono. 187) 


\section{Sosok Dewa indra}

Dari apa yang dikemukakan di atas ada beberapa hal yang perlu digaris bawahi sehubungan dengan figur Dewa Indra. Harus diakui bahwa sumber yang dipilih, walaupun mewakili tiga bentuk karya sastra, terlalu sedikit untuk dapat dijadikan pedoman dalam menggambarkan sosok Dewa Indra. Akan tetapi hal tersebut paling tidak dapat dijadikan sebagai gambaran awal tentang kecenderungan pujangga dalam menampilkan sosok Dewa Indra. Dengan anggapan bahwa para pujangga mewakili masyarakat pada masanya, maka kecenderungan tersebut dapat dikatakan sebagai pandangan masyarakat Jawa Kuna. Ada dua hal yang paling menonjol dan merupakan suatu kecenderungan penampilan Dewa Indra dalam karya sastra Jawa Kuna (periksa tabel)

Pertama Dewa Indra dalam kedudukannya sebagai penguasa surga atau langit yang disebut oleh enam dari tujuh karya sastra yang dipilin. Ke-dua berkaitan dengan aspek dinamis Dewa !ndra, dalam hat ini paling sedikit ada tiga aspek, yaitu berkaitan dengan perang, menghidupkan yang mati, dan menurunkan hujan. Aspek dinamis yang paling sering disebut adalah yang berkaitan dengan perang, menyusul menghidupkan yang mati dan menurunkan hujan.

Di samping itu karya sastra Jawa Kuna tersebut secara tidak langsung menggambarkan Dewa Indra mempunyai senjata berupa bajra dan kendaraan (vahana) berupa gajah besar. Bahkan Kakawin Arjunawiwaha menyebutkan bahwa gajah Dewa Indra bernama Erāwana

Hal lain yang menarik adalah disebutnya Dewa Indra dalam Kakawin Sutasoma yang berlatar agama Buddha. Hal ini menunjukkan bahwa Indra juga dikenal dalam agama Buddha dengan kedudukan dan aspek dinamis yang kurang lebih sama dengan agama Hindu

\section{Pengaruh Kebudayaan India}

Untuk mengetahui pengaruh kebudayaan india terhadap sosok Dewa Indra seperti yang tergambarkan dalam beberapa karya sastra Jawa Kuna terlebih dahulu patut ditinjau sedikit tentang Dewa Indra di India. Mitologi sebagai bagian penting dari kebudayaan India telah mengalami perjalanan waktu yang panjang, dari masa Veda sampai Hindu. Pada masa veda, dewa yang pa. ling dikenal dan menonjol adalah Indra. Jauh sebelum dewa-dewa Trimurti muncul, Indra telah dikenal sebagai raja para dewa yang menguasai tiga dunia: surga, langit, dan bumi. Di samping itu, Dewa Indra juga dianggap sabagai pengayom dan pemberi anugerah, dan menjamin surga pada manusia yang selalu memujanya (Baner jea, 1941: 82).
Pada masa Veda yang lebih kemudian, kedudukan Dewa Indra semakin turun. Pada masa Hindu, di mana susunan kedewaan dikua. sai oleh Tri Murti, Indra hanya dikenal sebagai dewa langit dan penjaga mata angin Timur. Tetapi anggapan yang paling menonjol adalah bahwa Indra tetap memimpin kelompok dewa minor dan apsara yang berkedudukan di surga bersama istrinya Indrani (Saci)

Sebagai dewa perang, Indra juga dikenal baik dalam masa Veda maupun Hindu. Pada masa Veda keperkasaan Indra antara laın ditunjukkan dengan mengalahkan Vitra, naga jahat yang membelenggu hujan (Drekmeier, 1962:14). Di samping itu beberapa syair menggambarkan bahwa Indra adalah dewa perang bangsa Arya yang selalu mengalahkan pasukan penduduk asli. Hal ini antara lain disebut dalam $R$ igveda (VIII, 85, 13-15) yang menceritakan Dewa Indra menghancurkan pasukan Krsna, pahlawan penduduk asli (Radhakrishnan, 1958: 87) Pandangan terhadap Dewa Indra pada masa selanjutnya sangat terkait dengan kedudukannya sebagai penguasa surga. Sehubungan dengan hal itu lons mengatakan bahwa tanpa letih dan tidak henti-hentinya, Indra selalu memerang; mahluk jahat (1967: 16).

Kemenangan indra atas Vitra berartı terbebasnya hujan dari belenggu Vịta. Mulai saat itulah Indra dipandang sebagai dewa hujan Demikian pula dengan atribut cirinya yaitu vajira, adalah senjata berupa 'petir' yang digunakan untuk menghantam Vrtra Sedangkan kendaraan Indra, yaitu gajah Airavata (Airavana), mulaı dikenal pada masa Hindu, yaitu ketika dia memimpin para dewa dalam pengadukan samudera untuk mencari air amerta (Shukla, 1958: 337).

Uraian tersebut dapat dilihat bahwa gambaran Dewa Indra di Indonesia sangat dekat dengan mitologi di India. Hal inı tampak, baik pada kedudukan maupun aspek dinamisnya, termasuk atributnya yaitu kendaraan dan senjatanya

\section{Penutup}

Dengan menyamarkan nama-nama tokoh dan tempat, penyair menyajikan sebuah gambar tentang tanah air dan masyarakatnya sendin, demikian pula dengan "settung" cerita merupakan "setting" Jawa (Zoetmulder, 1983:239) Lebih lanjut Zoetmulder menjelaskan keterangannya teru. tama yang menyangkut waktu dan musim, flora dan fauna, serta daerah pedesaan dan istana raja, yang tak perlu diragukan lagi sebagai "settıng" Jawa (ibid: 238-270). Dengan demikian tentu saja didalamnya terdapat pokok-pokok di mana kita berkesempatan untuk meneropong beberapa aspek kehidupan masyarakat Jawa Kuna

Sastra Jawa Kuna identik dengan sastra kraton karena alasan-alasan tertentu, sepert 
kehidupan yang sebagıan besar menggambarkan kalangan kraton atau istana. Lingkungan inilah yang paling dikenal oleh penyair, dan tentu saja yang paling disukai, termasuk oleh penikmatnya. Apakah hal Inı berkaitan dengan kecenderungan penyair dalam menampilkan sosok Dewa Indra, bukanlah pertanyaan yang mudah dijawab. Meskipun demikian, kenyataan tersebut memandu kita untuk mempertimbangkan hal itu, sehıngga didapat kesan bahwa penyair lebih suka pada Dewa indra yang menguasai surga dan aspek dinamisnya, beserta kemegahan figur penguasa. Selanjutnya bisa diandaikan bahwa sosok Indra tersebut merupakan figur ideal seorang penguasa atau raja yang diinginkan baik oleh penyair maupun masyarakat pada waktu itu. Dalam kesenian wayang pun Dewa Indra tetap dianggap sebagai pemimpın para dewa dan bidadari, serta bertanggung jawab atas segala hal di surga (Hardjowirogo, 1968: 29)

Penelitian yang lebih luas dan mendalam terhadap data tekstual pada masa yang akan datang diharapkan dapat mengungkap lebih jauh tentang kecenderungan pujangga atau penyair Jalam menggambarkan Dewa Indra. Lebih jauh lagı diharapkan dapat diketahui sekaligus dipahami tentang ałasan atau faktor-faktor yang melatari kecenderungan tersebut.

\section{KEPUSTAKAAN}

Aminoedın, Anıs, 1986, Penelitian Bahasa dan Sastra dalam Naskah Sri Tañjung di Banyuwangi, Jakarta: P3B

Banerjea, J. N. 1941, Development of Hindu Iconography Calcutta: University of Calcutia

Boecnarı,1977. Epırafı dan Sejarah Indonesia, Majalah Arkeologi Th 1 no $1 \mathrm{hlm}$. 35-54

Drekmeier Charles,1962, Kingship and Community in Early India, Stanford: Stanford University Press

Hardjowirogo, 1968, Sedjarah Wayang Purwo Djakarta P. N. Balai Pustaka
Ions, Veronica, 1967, Indian Mythology: London Paul Hamlyn.

Poerbatjaraka,R Ng., 1957, Kepustakaan Djawa Djakarta Djambatan

Prijono, 1938, Sri Tañjung, een Oud-Javaanshe Verhaal, Leiden: Proefschrift Rıjks Universiteit Leiden

Radhakrishnan, 1958, Indian Philosophy, vol. I London: George Allen \& Unwin Ltd

Santoso,Soewito, 1975, Sutasoma A Study in Ja. vanese Wajrayana, New Delhi IAIC

Sedyawati,Edi, 1978, Iconographical Data from Old Javanese Kakawins Majalah Arkeologi no. 1. September.

Shukla,D.N.,1958, Vastusastra vol. II, Hindu Canon of Iconography and Painting Gorakhpur: Gorakhpur University

Wirjosuparto,Sutjipto, 1968, Kakawin Bharatayuddha, Djakarta: Penerbit Bhratara

Wiryamartana, I.Kuntara, 1987, Arjunaw/waha Transformasi Teks Jawa Kuna Lewat Tanggapan dalam Lingkungan Sastra Jawa Kuna, Disertasi, Yogyakarta: FS UGM.

Zoetmulder, P J., Kakawin Ramayana, naskah ketikan, tidak diterbitkan

Zoetmulder, Udyogaparwa, naskah ketikan tıdak diterbitkan

Zoetmulder, 1983, Kalangwan, Sastra Jawa Kuna Sela-yang Pandang terjemahan Dick Hartoko, Jakarta: Djambatan. 


\begin{tabular}{|c|c|c|c|c|c|c|c|c|c|}
\hline \multirow{3}{*}{ No } & \multirow{3}{*}{ KARYA SASTRA } & \multirow{3}{*}{ BENTUK } & \multicolumn{4}{|c|}{ SOSOK DEWA INDRA } & \multicolumn{2}{|c|}{ IKONOGRAFIS } & \multirow{3}{*}{ KETERANGAN } \\
\hline & & & \multirow{2}{*}{$\begin{array}{l}\text { Kecuditan } \\
\text { (Penguasa } \\
\text { suraa) }\end{array}$} & \multicolumn{3}{|c|}{ Asp. Dinamis } & \multirow{2}{*}{$\begin{array}{l}\text { Vahana } \\
\text { (Gajah) }\end{array}$} & \multirow{2}{*}{$\begin{array}{l}\text { Senjata } \\
\text { (Bajra) }\end{array}$} & \\
\hline & & & & 1 & 2 & 3 & & & \\
\hline 1. & Ramayana & Kakawin & - & 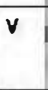 & - & $v$ & - & - & $\begin{array}{l}-X X \mid V: 13, a-b \\
-X X I V: 53, a-b\end{array}$ \\
\hline 2. & Udyogapanwa & Prosa & - & $v$ & - & - & - & $\mathbf{v}$ & $\begin{array}{l}\text { bagian cerita } \\
\text { indramijaya }\end{array}$ \\
\hline 3. & Arjunawiwaha & Kakawin & 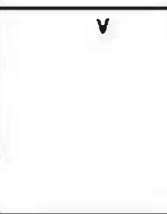 & 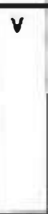 & $\mathbf{v}$ & - & 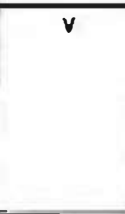 & - & $\begin{array}{l}\text {-awal losah } \\
\text {-XXIII: 1, a-c } \\
\text {-XXVIII: 3, b } \\
\text {-XXIII: 1, b } \\
\text {-XXIII: 1, c }\end{array}$ \\
\hline 4. & Smaradahana & Kakawin & $v$ & $v$ & $\cdot$ & - & $v$ & - & $\begin{array}{l}-X X \mid X: 6, c \\
-X X X \mid 1: 6, a-b \\
-X X X \| 1: 6, a-b\end{array}$ \\
\hline 5. & Bharatayuddha & Kakawin & $v$ & $\mathbf{v}$ & - & 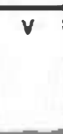 & - & $\cdot$ & $\begin{array}{l}-1 X: 2, d \\
-1 x: 2, d \\
-1 x: 2 . c\end{array}$ \\
\hline 6. & Sutasoma & Kakawin & $\checkmark$ & - & $v$ & $\overline{-}$ & $=$ & - & $\begin{array}{l}-X X X V \mid: 3 . \text { a } \\
\text {-XXXYI: 3, a } \\
\text { dan CXLVII: } 8 \\
c-d\end{array}$ \\
\hline 7 & Sri Tañung & Kidung & $v$ & $\cdot$ & $=$ & $\cdot$ & - & - & $-111: 32, a-d$ \\
\hline
\end{tabular}

\section{Keterangan:}

1 = berkaitan dengan perang

2 = menghidupkan yang mati

$3=$ menurunkan hujan

$v=$ menyebutkan

- = tidak menyebutkan 